\title{
Urks and the Urban Subsurface as Geosocial Formation
}

Björn Wallsten and Joakim Krook

\section{Linköping University Post Print}

\section{Tweet}

N.B.: When citing this work, cite the original article.

Original Publication:

Björn Wallsten and Joakim Krook, Urks and the Urban Subsurface as Geosocial Formation, 2016, Science, Technology and Human Values.

http://dx.doi.org/10.1177/0162243916634866

Copyright: SAGE Publications (UK and US)

http://www.uk.sagepub.com/home.nav

Postprint available at: Linköping University Electronic Press

http://urn.kb.se/resolve?urn=urn:nbn:se:liu:diva-122760 


\section{Urks and the Urban Subsurface as Geosocial Formation}

Authors: Björn Wallsten ${ }^{\mathrm{a}^{*}} \&$ Joakim Krook $^{\mathrm{b}}$

Published in Science, Technology and Human Values.

DOI: $10.1177 / 0162243916634866$

a Department of Thematic Studies, Technology and Social Change, Linköping University, SE-581 83 Linköping, Sweden

${ }^{\mathrm{b}}$ Department of Management and Engineering, Environmental Technology and Management, Linköping University, SE-581 83 Linköping, Sweden

* Corresponding author. Tel: +46702891883 Email: bjorn.wallsten@liu.se

\section{Abstract}

This article investigates "urks", i.e., disconnected parts of urban infrastructure that remain in their subsurface location. The reason for engaging in this topic is resource scarcity concerns, as urks contain large amounts of copper and aluminum that could be "mined" for the benefit of the environment. Our starting point is that there is a certain non-stagnant capacity of waste-like entities such as urks and that their resistance to categorization is crucial to encapsulate their political potential (cf. Hawkins, 2006; Moore, 2012; Hird, 2013). We investigate how this indeterminate capacity has implications in terms of where future trajectories for urk recovery are conceivable. The study is based on interviews with respondents from the infrastructure and waste sectors in Sweden. By stressing the relationship between urks and their geo-social subsurface surroundings, we use the respondents' exploratory interpretations of urks to outline a spectrum of issues that should be further discussed for urks to become a matter of concern. The negotiation of these issues, we suggest, can be conceived of as a form of navigation along the perceived fault lines between actors and priorities, and they must be resolved for increased urk recovery to occur.

Keywords: politics, power, governance, environmental practices, infrastructure, urban mining 


\section{Introduction}

Infrastructure systems have a certain geological relevance. For example, the quantities of copper in the Swedish telecom and electricity systems are comparable to the reserves left in Aitik, Sweden's largest copper mine (Krook and Baas 2013). This is an indication of how the infrastructuredriven process of urbanization has not only reconfigured specific landscapes, but also the geological strata of planet Earth; infrastructures are geo-social entities, i.e., both geological and social simultaneously (see Clark 2013). Infrastructure has increasingly been suggested as a secondary resource base for so-called "urban mining," i.e., recovery strategies aimed at recycling material stocks in the built environment (cf. UNEP 2010; Krook et al. 2011).

In line with these suggestions, we investigate "urks," a term we coined to denote infrastructure cables and pipes that remain underground after being disconnected. ${ }^{1}$ Urks are particularly interesting from an urban mining perspective since, no longer in use, they are theoretically available for recovery. While most infrastructure parts are functional and in service, urks may account for as much as one-fourth of the weight of a Swedish city's infrastructure and contain significant amounts of copper, aluminium and steel (Wallsten et al. 2013a).

However, urks are a non-issue in Sweden, as no one is engaged with their recovery or prevention of further accumulation. Regulations are too weak to enforce recovery (urks pose no immediate environmental risk) and economic incentives are non-existent (revenues from recycling do not meet the costs of recovery). This is problematic, since urks are a hidden example of a persistently wasteful use of resources, and for ethical reasons as well, exemplified by the relatively high amounts of copper in-use per person in Sweden. Based on UN projections of a future global population of 10 billion and estimates of extraction provided by Zittel et al. (2012), Exner et al. (2014) arrive at an approximate average of $100 \mathrm{~kg}$ per person if planetary amounts of available copper were distributed equally. Fifteen years ago, the Swedish number was $189 \mathrm{~kg}$ of copper per person (Rauch 2009), while for countries in the Global South it was 30-40 kg (Gerst and Graedel 2008). For Sweden to contribute its share to the goal of equal global access to copper would involve halving the country's in-use copper stocks. Urk mining as well as interventions to prevent further urk accumulation could contribute to realizing such an ambition.

This article argues that Swedish infrastructure should be reconfigured to incorporate the recovery of disconnected components. Our ambition is, first, to turn urks from matters of fact (concerning their numbers, internal composition, etc.) to matters of concern by highlighting aspects that need 
to be politically resolved for increased urk recovery (Latour 2004); our second ambition is to open a debate on political interventions for increased urk recovery by including them as internal system entities in our analysis. Inspired by previous research on how indeterminate qualities of waste can create room for dialogue and decision making (e.g. Moore 2012; Hird 2013), we examine how a multitude of plausible ontological claims (i.e., conceptual interpretations based on the materiality of urks) affects how the subsurface realm of cities can be perceived. We connect these understandings to different unresolved matters where political decisionmaking for increased urk recovery might intervene, and analyze what is at stake there for infrastructure-related actors and society at large.

\section{Social Studies of Infrastructure}

The starting point for this article is that decay and non-functioning are given features of infrastructures, which are premised on a certain degree of failure as a normal condition (Petroski 1985, referenced in Graham and Thrift 2007). Yet, previous social science research on disconnected cables and pipes is nearly non-existent, and authors have observed (1) how there is still a knowledge gap regarding underutilized network spaces (Moss 2008 p. 439); (2) that relatively little is known about infrastructure system decline in general (Gandy 2005); and (3) that there are few explicit accounts of how infrastructure systems are discontinued or un-made (Weber and Salehabadi 2012). This is in some sense also mirrored in theoretical models of Science and Technology Studies in which "the other side of the coin," i.e., processes of exclusion, are often neglected (Galis and Lee 2014).

A tentative reason for this neglect is that both infrastructure and waste are usually more or less invisible entities. Many scholars have asserted that infrastructure systems are least visible when they perform their function (cf. Guy et al. 1997; Star 1999; Nye 2010). But invisibility is equally present in relation to waste produced in our technological societies: like other wasterelated materials, disconnected cables and pipes are kept from view in a perceptual back region (Goffman 1971). While infrastructure scholars might recognize their object of inquiry's relative invisibility, this does not automatically mean that they are sensitive to the solid waste produced by and associated with the systems they study. As both infrastructure systems and waste are seen as back-staged, "hidden" urban entities, urks are in a sense veiled behind double curtains of invisibility. The domain of urks is a backstage within a backstage. 


\section{Where There Is System There Is Dirt}

If infrastructures "were ever concealed or backgrounded, it was to or by those in hegemonic social positions" (McFarlane and Rutherford $2008 \mathrm{p}$. 371). To be sure, this is also true for urks, as their removal would imply higher costs for any of the actors involved in the provision of infrastructure. For system owners, for example, it makes economic sense to demarcate urks as external to the sphere of economic relationships in which they operate (cf. Callon 1998).

Jennifer Gabrys (2009) has suggested sinks, i.e., environmental zones that function as repositories for waste, as sites for fruitful investigation of the boundaries between systems and waste. She (2009) voices a plea for an understanding of sinks as "indeterminate hybrids of waste, technology, ecology, humans, and non-humans" (p. 667) and suggests that the ambiguities of "these deep spaces where waste is channelled and stored" (p. 668) should be traversed to develop a sink theory. The analytical thrust of this article adheres, like Gabrys, to the growing body of literature that places a particular emphasis on the non-stagnant, indeterminate capacities of waste (cf. Hawkins 2006; Hird 2013), and how its resistance to categorization is crucial to encapsulate its political potential (Moore 2012).

Urks are indeed waste-like: many possible claims can be made about them, depending on which of their materialities that is emphasized, e.g., their metallic or possibly hazardous content. Urks allow for a certain interpretative flexibility (Pinch and Bijker 1987), i.e., there are various possible urk types as well as ways to conceptualize them. The variety of interpretative possibilities is however not endless, as the materiality of urks permits as well as prohibits certain claims (cf. Akrich and Latour 1992). Woolgar and Cooper (1999) have observed that the inherent ambivalence of technological artifacts might be used "as a lever for discerning the relationships between the different parties involved" (p. 443). Rather than providing a discussion of how politics should intervene, we used this insight in our analysis of the urk interpretations to also outline a spectrum of where politics can (or even must) intervene to create trajectories for increased urk recovery. It is the possibility to interpret urks in different ways that harbour their political potential, since different interpretations suggest different matters of concern that must be resolved for their increased recovery.

Altering the configuration of mature infrastructure systems is not easy, as they have been consolidated within a wide net of actors and organizational arrangements to ensure their sustained functioning (Hughes, 1983). However, either internal or external forces can challenge phases of relative stability. An awareness of the environmental impact of infrastructures, their "negative externalities" (May 2011), can be used to increase pressure 
towards altered system configurations (Summerton 1994). In this article, we mobilize the inherent ambivalence of urks as a rhetorical device to reconsider infrastructural practices, policies and regulation for a broader constituency (cf. Hird 2013), intent on advancing urks as an urgent matter that can create pressure towards infrastructural re-configuration.

\section{The Study's Underpinnings}

This study is part of a research program on secondary resource extraction in Sweden, encompassing studies of both urban and landfill mining (cf. Krook et al. 2011; Frändegård et al. 2015; Johansson and Metzger 2016). Previous studies within this program have focused on the weight and spatial characteristics of urks (Wallsten et al. 2013a), the underlying reasons for why urks occur in relation to maintenance and repair processes (Wallsten et al. 2013b) and the spatially contingent conditions of urk recovery (Wallsten et al. 2015). As we have shown that urks exist in all major infrastructure systems in Swedish cities (Wallsten et al. 2013b), we herein apply an integrated view that treats the urban infrastructure as a bundle, enabling the possibility to study interdependencies among different systems, and identify similar trends in each of them (cf. Graham and Marvin 2001).

\section{Gathering the Empirical Material}

Since urks have left few traces in Swedish public records, we chose to gather empirical data through interviews with respondents with experience from the infrastructure and waste sectors. The ambition was to encapsulate different perspectives (e.g. legislation, management, landowning, recycling and maintenance) and cover a variety of knowledge, from hands-on experience of infrastructure maintenance and repair, to Swedish mineral resource politics and waste legislation. Respondents were selected from the Swedish Ministry of Environment (SME) and Environmental Protection Agency (EPA) to represent relevant national agencies; respondents from a major metal recycling company and the Swedish Recyclers Association (SRA) were also included from the waste sector. Respondents from the Technical Administration and Environment and Health offices of two municipalities were chosen together with one cable consultant and employees from two infrastructure system owners and one construction company.

We conducted semi-structured interviews according to four overarching themes: (1) the perception of urks; (2) their jurisdictional and policy framing; (3) matters of ownership and responsibility; and (4) the 
possibilities for and hindrances to managing their accumulation and continued presence. Twelve interviews were conducted face-to-face with fourteen people in the spring of 2012. All conversations were recorded and transcribed: the analyzed material encompasses approximately 100 pages.

\section{Method of Analysis}

In our analysis, we have not emphasized the respondents' backgrounds and their claims have not been regarded as official statements from the organizations they represent. Nor have we emphasized why certain actors interpret urks in a certain way or positioned the respondents' claims in relation to one another. This is because we realized as we conducted the interviews that the responses ranged into unknown territory: this was apparently the first time the respondents were asked specifically about urks and their answers were formulated as preliminary thoughts that developed as the interviews proceeded. Given this, the interviews explored what urks are and how they could become otherwise, and our analytical ambition has been to consider the interviewees' statements as well-informed claims made in a world characterized by great uncertainty (cf. Callon et al. 2009). The systems the respondents chose to talk most about were cable-based (electricity, street lighting, traffic signals and telecom grids), which share metallic properties insofar as they contain copper and aluminium.

Our analysis relied on thorough reading of the transcribed material while continuously underlining claims about urks and where in the material these claims surfaced. In this coding process we found no common sense of how urks should be understood, but we were able to identify five different interpretations of urks, all based on their physical characteristics, design and contents.

The relation between urks and their surroundings was apparent in the respondents' answers, indicating a strong relationship between how urks are understood as singular entities and the way the world underneath Swedish streetscapes is characterized. The respondents regarded plurality to be a valid observation about the urban subsurface and argued that if a single urk was $\mathrm{X}$, then the urban underground was $\mathrm{Y}$ since urks in the urban underground are many. In addition to the five different urk interpretations, we were able to distinguish five corresponding geo-social formations of the urban underground in the material.

In the discussion, we outline a spectrum of suggestions of where politics might intervene to alter the configuration of infrastructure to also include urk recovery. For example, these consist of legislation, contracts, business models and environmental quality objectives that have varying impact on 
infrastructure-related actors as well as society at large. The outlined spectrum is not exhaustive; there might be alternatives that the respondents did not think of, and in certain cases we have backed the claims up with relevant pieces of legislation, archival observations, previous research and so on.

\section{Urks as Pollution Sources and the Urban Subsurface as Contaminated Soil}

Our respondents point out that urks may contain materials that are environmentally hazardous such as lead, oil, PCB, CFCs or asbestos, as emphasized by the respondent at the technical office of a Swedish municipality: "There are cases when [an urk] as such might entail an environmental risk." This focus frames the urk by its capability to dissipate hazardous substances to its nearby environment. Damage to urks enhances the risk of dissipation compared to connected, well-functioning system parts, or as a respondent from a municipal environment and health office puts it: "Sooner or later, everything that remains in the ground becomes an environmental risk." Since hazardous urks dissipate fluids and substances, collectively they enact the urban underground as a geo-social formation of contaminated soil.

In practice, it can be argued that this geo-social formation is convenient for those who might be held responsible for urk recovery, e.g., the system owners, municipal landowners or regulatory authorities. As the respondent at the SME remarked, it is "manageable to regard it as contaminated soil," since no actor is thereby forced to take immediate action for urk removal. The reason for why this is the case, is related to how contaminated soils are an indicator for the national environmental quality objective of a non-toxic environment (Miljömål.se 2014), and how the Swedish county administrative boards perform risk classifications of contaminated soil based on evaluations of the hazardousness of pollution sources, the conditions for dissipation and the protective value of the surroundings.

If urban undergrounds were included in these official risk classifications, they would score low in comparison with abandoned chemical industry sites, oil refineries or mines. For lead, zinc and PCB, investigations (cf. Palm and Östlund 1996; Neuendorff 2009) have for example only found only low degrees of dissipation from infrastructure, which the respondent from the metal recycling company was highly aware of: "It was found that the leakage of lead from lead-coated cables was tremendously small." Understanding the urban underground as contaminated soil effectively hides urk removal behind more obvious issues, that is, more highly polluted areas. The consequence of this interpretation is thus that urks continue, 
purposefully as it seems, to be a non-issue as they pose no immediate threat to the nearby environment.

One of the respondents at the EPA speculated about what could disturb such a stable enactment, concerning CFCs: "There are a lot of CFCs out there... that will dissipate, if it hasn't done so already. [...] I think it's politically troublesome to bring that up." The phase-out of CFCs in Sweden is generally regarded as a success (Martinsson 2001). While assessments need to confirm whether CFCs are actually widespread in urks, such an aspect could encapsulate seeds of controversy that could result in demands for more far-reaching soil remediation measures. There might also be other toxic materials in urks that have gone under the radar so far and that, given sufficient attention, could turn the geo-social formation of the urban underground as contaminated soil into a much more pressing concern.

\section{Urks as Resources and the Urban Subsurface as a Mineral Deposit}

Another material aspect of urks emphasized by several respondents is that they contain valuable metals that potentially could be recycled. This understanding implies that an urk has a monetary value that can be collected if it is dug up and sold. Given that any city is full of urks that could potentially be "mined," its urban underground can be characterized as a mineral deposit. This is the geo-social formation created by an understanding of urks as metallic resources.

The understanding of urks as a resource is however not sufficient to allow more than occasional urk recycling initiatives. Metal recycling is currently done for profit in a market setting, which implies that recycling revenues must outweigh expenses from extracting the urks. This is seldom the case, both due to the expense associated with street excavation (regulated by the municipal landowner) and the relatively low revenues for infrastructure scrap (which is decided by the recyclers' profit margins, global copper prices, available recycling technologies etc.) (Krook et al. 2015). The unfavourable economics of extraction is a predominant reason for urks' plentiful existence (Wallsten et al. 2013b).

The respondents point out that urk recycling actually does occur on certain occasions: redevelopment projects are one example of when this can happen on a significant scale. In such cases, urk extraction becomes an added value since the digging costs are paid whether urk recovery occurs or not. $^{2} \quad$ The respondent from a construction company mentioned that maintenance workers hold "cable parties," paid for by selling recovered urks for scrap. 
The contract that dictates excavation work in connection to such cases is written between the developer and a subcontractor, instead of between the system owner and a subcontractor responsible for excavation, which is normal procedure regarding everyday maintenance. System owners with system parts inside the larger redevelopment area are paid a lump sum for the expense of re-routing their system, after which they never actually engage with these parts again. These instances occur over longer time spans, in larger areas and with bigger working crews than the regular maintenance, and so the degree of subcontractor freedom is much larger and allows for further recycling efforts than the everyday maintenance operations which are regulated in "if feasible: recycle" contract terms. A notable difference is that it is the subcontractors, and not the system owners, who reap the rewards from the urk recycling.

From a societal point of view, urk extraction would tentatively mean that the Swedish reliance on mineral resources would be less environmentally burdensome. The respondent at SRA stressed that urks should be regarded as a resource: "Since we have a planet with limits and a limited amount of metals, let's use them as much as we can and recycle them as much as we can." That a significant mineral reserve can be located beneath the urban streetscape is a general idea among the respondents and expressed as evidence of the inefficient use of resources in society at large. For example, a respondent from the EPA even sees it as an indication of Sweden's low ambitions in this area, in comparison to Sweden's strong position in issues of climate change and the dispersion of chemicals.

Understood as mineral resources, metallic urks indicate the lack of a comprehensive national resource policy in Sweden. The opinion voiced by the informant above is confirmed by the absence of the Swedish Ministry of Environment on the steering committee of the International Resource Panel of the UN Environmental Programme. In this international context, resource questions are debated from scarcity concerns, the geopolitics of extractive industries, the potential of secondary reserves and so on. In the Swedish context, such a resource focus is lacking in the 16 environmental quality objectives that guide the overall goals of the nation's environmental policy. While several of these objectives touch on resource matters (e.g., mining) indirectly, none is primarily concerned with it. The objective for a good built environment has the most explicit formulation on infrastructure, stating that it should be located and designed with respect to a sustainable use of resources (Miljömål.se 2014).

The claim that the urban underground constitutes a mineral reserve theoretically available for recycling/re-use is then, however tentatively sound from an environmental perspective, not enough to find legislative or 
regulatory support for a reconfiguration of infrastructure provision. There is no environmental objective in which to anchor such a position, nor are mineral infrastructure reserves mentioned in the recently developed Swedish mineral strategy (cf. Johansson et al. 2014).

\section{Urks as Waste and the Urban Subsurface as Landfill}

A third urk interpretation emphasizes their quality of being broken, i.e., an urk exists because it malfunctioned. This understanding is based on the urk's functional capability, or lack thereof. To regard a broken urk as waste makes sense; what other possible reason could lie behind disconnecting and leaving an urk in the ground than the urge to discard something that no longer works? This matter is voiced among the interviewed respondents, as for example one from a municipal environmental and health office mentions: "It fulfils no function, nobody wants it, it's waste." The "wants it" phrasing is key since Swedish environmental law equates waste with intentionality: "Waste is an entity that its owner either wants to or has to discard" (SFS, 1998:808 chap.15, section 1). However, respondents disagree about whether this is actually the case with urks. The respondent from the metal recycling company expresses a completely contrary view: "According to the law it is not waste since... [...] waste demands the willed intention to discard it, and as long as they [the urks] remain in the ground that is not the case." The respondents elaborate upon the underlying reasons for why urks are left in the ground and disagree as to whether a broken urk actually is waste. Generally, they seem to have difficulty coping with the concept of waste in relation to urks. The respondent from the Ministry of Environment suggests that this uncertainty stems from misguided waste legislation: "The legal framework is not made to deal with such things [as urks]. In accordance with Swedish law, waste is something that is more directly connected to simple ways of disposal and that someone collects it." This is in opposition to the reality of urks, whose subsurface location presents an expensive and troublesome hassle to deal with.

Another reason why respondents are unsure whether urks are waste or not is that such an understanding could have major consequences. For example, the urks-as-waste interpretation would demand that the owner have a strategy for how to handle their removal, with added costs given the current configuration of subsurface infrastructure provision. A respondent from a municipal environment and health office is aware of these consequences: "It would be difficult if it was not anchored in legislation. [...] It would seem difficult if we were not allowed to write decisions and enforce them [the system owners] to do this." The respondent from the metal recycling company provides another perspective, stating that system 
owners "are afraid that it will increase their costs. That's why they aren't that interested." These quotes exemplify the tensions that an understanding of urks as waste creates, since it could potentially delegate the costly responsibility of urk removal to a certain actor.

Another consequence of understanding urks as waste is that it brings Swedish landfill legislation into the game. This law is based on spatiotemporal capacity and defines landfill as a storage location/facility for waste for a sequence of years. From the strict legislative standpoint, an urk cannot be part of a landfill until it celebrates its first birthday. According to the fifth paragraph in the waste regulation: "A landfill is not [emphasis added] a location or facility where waste has: [...]

2. been stored before it is recycled or treated, if storage occurs for a period shorter than three years, or

3. been stored before it is disposed of, if storage occurs for a period shorter than one year." (SFS, 2011:927)

This means that an urk during its first year of life might be regarded simply as waste without being part of an underground landfill, which is tentatively the case for a very small minority of urks but cannot be determined since their year of disconnection is seldom noted. Thereafter, the situation is turned as the underground's function as a location for accumulated wasteurks transforms the urban underground to a landfill. This is the geo-social formation of the urban underground that an understanding of urks as waste creates.

The respondent at the Ministry of Environment outlines what such an understanding entails: "It does comply with the waste definition. But... it is not possible in practice... Then our regulatory framework surrounding landfills and other things would collapse." The far-reaching consequences referred to here are the Swedish legal requirements on landfill safety measures. By law, Swedish landfills must be encapsulated and covered to prevent leachate from poisoning their nearby environments (Avfall Sverige 2012), so two alternatives emerge: either all Swedish cities are required to engage in preventive measures against underground leakage, or the landfill legislation which generally is described as a success story is amended (Corvellec and Hultman 2012). Since the first option is far-fetched and practically impossible and the second highly undesirable, there is every reason for the involved actors to avoid the trajectory that the understanding of urks as waste entails - both since it has the capacity to reconfigure infrastructure in a way that delegates the costly responsibility of urk recovery to this or that actor, and since it actualizes the urban underground as landfill. 


\section{Urks as Spare Parts and the Urban Subsurface as Underground Storage}

A fourth aspect mentioned in the interviews that can form a basis for how to understand urks is when they are fully functioning. The reason why such urks are left in the urban underground might seem counterintuitive at first, but it stems from how the cause of disconnection can be that a particular system part is no longer required to ensure that the system works as a whole. A reason for the disconnection of a functioning urk can be, for example, when the re-routing of a system occurs as a consequence of a densification project when a park or parking structure gives way to housing construction (Wallsten et al. 2013b). The respondents conclude that the reason functioning urks are left in the ground is because they might be reconnected to the system at a later point, which potentially results in the notion that the urban underground is a scrap yard or underground storage, from where it is possible to re-engage urks if there is a future need.

In practice, both system owners and landowners might use such an understanding of urks as functioning as an excuse. To say that you might have use for a particular urk in the future is not the same as actually having the intention use it. Instead, the "it is functioning" argument elegantly avoids the understanding of urks as waste (derived as it is from the owner's intention) and thereby also the responsibility for urk removal. A particular case of this is when a factory that is connected to the main infrastructure with its own system parts on municipally owned land shuts down or relocates. In the contracts between factory owner and municipality, clauses such as "At present, there is no demand to use [the urks], future use might however eventually occur" (Sköld, personal archive) are common. It is not difficult to envision that such claims are just a way to avoid the costs of restoration.

How then can it be possible that the understanding of urks as functioning and the urban underground as a storage facility creates a possible excuse not to engage with them as waste? An inventory was launched in 2011 by the former Swedish Minister for the Environment to survey all areas where Sweden could be brought before the Court of Justice of the European Communities. This inventory identified underground storage as an area where Swedish legislation was inadequate and in need of further accommodation to align with EU regulations. Or, in the words of the respondent at the SME: "There is a loophole in Swedish law for that which you leave down below." Since underground storage is incorporated in this legal document, urks understood as spare parts will have to be considered when the EU landfill directive is to be fully implemented in Sweden. 


\section{Urks as Occupiers and the Urban Subsurface as Congestion}

A final interpretation that we found is that urks are occupiers of the urban underground. The subsurface world of industrialized cities is a geo-social clutter even without considering urks: a sedimentary "cables 'n' pipes salad" that maintenance workers explore with maps consisting of information that is not always accurate and/or updated. Maintenance work on infrastructure systems has been characterized by how "almost every new excavation involves a voyage of exploration" (Baines 1993, p. 56, quoted in Marvin and Slater 1997). An example of how urks resurface and affect infrastructure work is that in the same shaft two identical cables belonging to the system to be repaired might be found: one active with high-voltage current running through it and one disconnected and not represented on the map. While urks in this way do not contribute to the functioning of the infrastructure, they nevertheless affect its overall efficacy as they increase costs and work time by adding uncertainty, risk and inconvenience to the maintenance and repair processes. Removing urks from cluttered subsurface spaces would thus come with future benefits, as the respondent from the metal recycling company remarks: "If you can remove cables that are not in use, that will facilitate future digworks, [so] that they won't hinder digging or drilling." Emphasized as occupiers, urks in this sense enact the urban underground as geo-social congestion.

The diminishing amount of underground space available for installations and replacements is occasionally enough to motivate the removal of particular urks. Predominantly, this occurs in central areas that have had infrastructure systems installed for a long time. A respondent from a system owner mentions how they brought the matter to the attention of a municipal landowner who in turn "wanted to take the removal of our old pipes into consideration, more since there are quite a lot [of] different grid parts in the ground that... it is starting to get crowded".

The same respondent deemed the additional costs required for urk removal too high for them to further re-make their overall strategies regarding urk governance. If changes were to occur that would require the removal of urks, however, the respondent expressed that: "It would not be impossible for us, indirectly it was us who brought the matter to the fore for reasons of crowdedness. [...] But, we would need completely different business models to investigate how we could manage such a thing."

Since the deregulation of several of the Swedish infrastructure sectors, a predominant business model for infrastructure maintenance and repair is based on short procurement contracts that create intense time and cost pressures since they are based on lowest price. Because of this, respondents in one of our previous studies (Wallsten et al. 2013b), argued that urks was 
a phenomenon that is on the increase, since the configuration is more or less rigged for careless installations. It was pointed out, for example, that the deregulation had increased the level of complexity in the infrastructural set-up, as there are now more actors (diggers, subcontractors and so on) present in the urban underground. Accordingly, they believed that this had resulted in more excavations and decreased the possibilities to synchronize maintenance and repair-work. Since all of these aspects are indications that urk accumulation is increasing, the current configuration based on procurement of maintenance services would thus eventually be at stake if this were to continue. In the long-term perspective, the deregulated maintenance-and-repair procurement model seems to undermine its own legacy, if the continued accumulation of urks as occupiers will eventually cause enough obstacles and increased costs to require changes in infrastructure configuration.

\section{A Spectrum for Political Interventions for Increased Urk Recovery}

The different possible interpretations of urks are not passive. While some of them contain seeds for change towards more progressive urk interpretations (waste, resources and occupiers), the conservative conceptions (pollution sources and spare parts) can easily be mobilized to keep the current status of urks as a non-issue in place. As long as the latter prevails, the underground becomes incrementally more hazardous and crowded with resources, waste, spare parts and occupiers, that is: the accumulation and continued presence of urks will continue to be evidence of our society's suboptimal use of minerals. None of the suggested interpretations is forceful enough to alter the current configuration of infrastructure towards less wastefulness by itself, indicating that there are further matters that need to be resolved before urks can be transformed from a non-issue to something that is worth paying attention to.

All the respondents agree that urks are resources whose recovery would be generally beneficial. Since urk mining is not economically profitable and no existing regulation is powerful enough to produce change, the task for politics of increased urk recovery is to locate where decision making can intervene and resolve the controversies found there. Several alternatives emerged during the interviews with the respondents that could all be linked to how urks were interpreted.

A first matter to resolve for increased urk recovery is observed between the infrastructure owner and maintenance subcontractor. This matter has two aspects. The first is whether the deregulated arrangement with outsourced maintenance crews is the best set-up for urk recovery. Given indications of how the outsourcing of maintenance has been accommodated with 
increased time- and cost-pressures that further prevent urks from being recovered (Wallsten et al, 2013b), it is worth debating whether the current infrastructure maintenance arrangement could be improved if performed otherwise, a debate that is for example currently on-going in the case of the Swedish national railroads. The second aspect is of an economic nature, as it can be debated who should reap the rewards if recycling becomes, or indeed is made, profitable: is it the owner of the system parts or is it the subcontractors? The respondents expressed that the only instances when urk recycling is done in any significant degree are when the subcontractors themselves reap the benefit from the recycling, which predominantly happens in relation to larger redevelopment projects. The main issue to be resolved with regard to this matter of urk concern is how recycling initiatives could be arranged to fit either the business models of the system owners, or be a formalized part of the subcontractors operations.

A second matter in need of clarification regards the system owners and municipal landowners. For example, a more forceful "urk-as-waste" interpretation would mean that costs now avoided by all parties through the "urks-as-hazardous interpretation" can be delegated to either one of these actors. If the system owner's costs for street excavation are lowered (e.g., by regulating the municipal landowner's digging fees), then the municipality misses out on significant revenues. Sharpened regulations to enforce urk recovery would, on the other hand, result in increased costs for the system owner (likely paid for by users in the form of higher tariffs). While the general opinion among the respondents is that urk recovery should be the responsibility of their owners, the Swedish laws are written to prevent environmental measures from being unreasonably costly. The task in this particular issue is thus to negotiate the economics in a way that is acceptable to the concerned actors, and weigh short-term economic efficiency gains against longer term resource efficiency ones. Arguably, both the system owners and municipal landowners could be convinced that potentially raised expenses are reasonable given the environmental benefits they result in, and hence be based on the argument that an expense today does not need to be perceived as a cost but rather as an investment for the future.

A third matter in need of resolution, also suggested by the urks-as-waste interpretation, is the profit margins of the metal recyclers in relation to the economic incentives of system owners or subcontractors to engage in urk recovery. Metal recyclers pay relatively little for urks since they are trapped in Catch 22-like logics. This is especially true for old paper-coated cables in the Swedish power grid (Krook et al. 2015): since these have not been systematically collected, the amounts arriving to metal recyclers have been too small to motivate investments in developing automated recycling 
equipment. Therefore, paper-coated urks are largely recycled manually (a more expensive process), making the recyclers unwilling to pay enough to create incentives for their systematic collection. In the current situation, none of the involved actors has any economic incentive to expand urk recovery, and politics thus has a tentative role to play in resolving this dilemma (for example, by stimulating investments in new recycling technologies). On the other hand, and since the recycling sector is engaged in this matter from a profit interest perspective, a key problem is that only economic incentives seem to guide their actions. If they were motivated by other incentives, such as environmental or ethical ones, urk recovery would perhaps have a better chance of being implemented.

A fourth matter that needs a solution can be noticed in how urks (interpreted as "resources") can activate a debate concerning the prioritizing primary production of metals and secondary recovery. Swedish mineral resource politics has long been arranged so that recycling is massively under-supported in comparison to primary extraction (Johansson et al. 2014). The key negotiation at stake here concerns whether Sweden should be known as a mining country (as emphasized in the Mineral Strategy) or for its metal recycling ambitions, as well as what the prospects of these two strategies are for the future.

A fifth unsettled matter detected in the material relates to how different environmental concerns might be in conflict with one another, and if so, how priorities among them are set. Historically, Sweden's position as a front-runner on issues of climate change and chemical legislation has not been coupled with thorough policies concerning our natural resource use. Increased urk recovery could contribute further the Environmental Objective of designing a built environment with a sustainable use of resources. However, the non-toxic environmental objective prevents this from happening, insofar as the extensive Swedish legislation on contaminated soils and landfills lets urks remain a non-issue. The key question that arises is how different environmental objectives should be prioritized and on what basis. 


\section{Concluding Remarks}

The different matters that are in need of a resolution provide examples of the tensions that allow urks to remain a non-issue. The spectrum of where politics for increased urk recovery can intervene range from the International Resource Panel of the UN, via the national Swedish Environmental Code, Quality Objectives and different pieces of legislation, to the locally engaged actors and contracts in the Swedish infrastructure configuration. While all the matters of concern outlined above have a relationship to the Urk World, it is arguably insufficient to intervene only in one or two of them. For example, it is likely not enough to only develop new cable recycling processes, to reverse the outsourcing of repair crews or lower the restoration costs when digging in the streets, to achieve increased urk recovery. Rather, an orchestrated effort seems needed that consist of a multitude of combined and aligned changes to achieve consistency. National and municipal metal recycling targets should preferably be anchored in legislation and imply concrete and practice-related changes in business models, budgets, and contract formulations. Finding trajectories along the fault lines associated with the concerns suggested in the interviews is the central task for any techno-political achievements in this matter. In the larger perspective, urk politics boils down to a matter of what kind of society we want to create for ourselves, and the significance we appoint to urk recovery for the achievement of that society. Since it concerns our future reliance on mineral resources, we must engage in that task with commitment, using urks' multiple existence and inherent indeterminacy as food for thought and fuel for further debate.

\section{Notes}

1 "Urk" is an abbreviation often found on old Swedish infrastructure maps, for "urkopplad," the Swedish word for "disconnected." We use it untranslated to keep its onomatopoetic qualities and since it's a convenient shorthand for "disconnected piece of infrastructure that remains in its subsurface location."

${ }^{2}$ In these instances, the urban underground is transformed from a deposit to a reserve, a mining term signifying a so-called "workable" mineral deposit, i.e., one from which it is economically profitable to extract minerals. 


\section{References}

Akrich, Madeleine, and Bruno Latour. 1992. "A Summary of a Convenient Vocabulary for the Semiotics of Human and Nonhuman Assemblies." In Shaping Technology/Building Society, Wiebe Bijker and John Law (eds.). Cambridge, MA: MIT Press, 259-264.

Avfall Sverige. 2012. Avfall Sveriges Deponihandbok: reviderad handbok för deponering som en del av modern avfallshantering. (Rapport D2012:2, ISBN 1103-4092).

Baines, Chris. 1993. "Trench Warfare." BBC Wildlife, December, 56-57.

Callon, Michel. 1998. "An Essay on Framing and Overflowing: Economic Externalities Revisited by Sociology.” In The Laws of the Markets, Michel Callon (ed.). Oxford: Blackwell, 244-269.

Callon, Michel, Pierre Lascoumes, and Yannick Barthe. 2009. Acting in an Uncertain World. Cambridge, MA: The MIT Press.

Clark, Nigel. 2013. "400PPM: Regime Change in Geo-Social Formations." Society E Space Forum. July. Accessed October 27, 2015.

http://societyandspace.com/material/discussion-forum/400ppm/nigelclark-400ppm-regime-change-in-geo-social-formations/

Corvellec Hervé, and Johan Hultman. 2012. "From 'less landfilling' to 'wasting less' - societal narratives, socio-materiality and organizations." Journal of Organizational Change Management 25(2), 297-314.

Exner, Andreas, Lauk, Christian, and Werner Zittel. 2014. "Sold Futures? The Global Availability of Metals and Economic Growth at the Peripheries: Distribution and Regulation in a Degrowth Perspective." Antipode 47(2), 342-359.

Frändegård, Per, Krook, Joakim, and Niclas Svensson. 2015. "Integrating Remediation and Resource Recovery: On the Economic Conditions of Landfill Mining." Waste Management 42, 137-147.

Gabrys, Jennifer. 2009. "Sink: The Dirt of Systems." Environment and Planning D 27, 666-681.

Galis, Vasilis, and Francis Lee. 2014. "A Sociology of Treason: The Construction of Weakness." Science, Technology, $\mathfrak{G}$ Human Values 39(1), 154-179.

Gandy, Matthew. 2005. "Cyborg Urbanization: Complexity and Monstrosity in the Contemporary City." International Journal of Urban and Regional Research 29(1), 26-49. 
Gerst, Michael D., and Thomas E. Graedel. 2008. "In-use Stocks of Metals: Status and Implications." Environmental Science and Technology 42, 7038-7045.

Goffman, Erving. 1971. The Presentation of Self in Everyday Life. Harmondsworth: Penguin.

Graham, Stephen, and Simon Marvin. 2001. Splintering Urbanism. London/New York: Routledge.

Graham, Stephen, and Nigel Thrift. 2007. "Out of Order: Understanding Repair and Maintenance.” Theory, Culture Eீ Society 24(3), 1-25.

Guy, Simon, Graham, Stephen and Simon Marvin. 1997. "Splintering networks: cities and technical networks in 1990s Britain." Urban Studies 34(2), 191-216.

Hawkins, Gay. 2006. The Ethics of Waste. Lanham, MI: Rowman and Littlefield.

Hird, Myra J. 2013. "Is Waste Indeterminacy Useful? A Response to Zsuzsa Gille.” Social Epistemology Review and Reply Collective 2(6), 28-33.

Hughes, Thomas P. 1983. Networks of Power. Baltimore: Johns Hopkins University Press.

Johansson, Nils, Joakim Krook, and Mats Eklund. 2014. "Institutional conditions for Swedish metal production: A comparison of subsidies to metal mining and metal recycling." Resources Policy 41, 72-82.

Johansson, Nils, and Jonathan Metzger. 2016. "Experimentalizing the Organisation of Objects: Re-enacting Mines and Landfills.” Organization. DOI: $10.1177 / 1350508415624271$

Krook, Joakim, Carlsson, Annica, Eklund, Mats, Frändegård, Per, Svensson, Niclas. 2011. "Urban mining: hibernating copper stocks in local power grids.” Journal of Cleaner Production 19 1052-1056.

Krook, Joakim, and Leo Baas. 2013. "Getting Serious About Mining the Technosphere: A Review of Recent Landfill Mining and Urban Mining Research.” Journal of Cleaner Production 55, 1-9.

Krook, Joakim, Svensson, Niclas, and Björn Wallsten. 2015. "Urban Infrastructure Mines: On the Economic and Environmental Motives of Cable Recovery From Subsurface Power Grids.” Journal of Cleaner Production 104, 353-363. 
Latour, Bruno. 2004. Politics of Nature. Cambridge, MA: Harvard University Press.

Martinsson, Mathias. 2001. Ozonskiktet och risksamhället. Diss. Linköping: Teknik och social förändring, Tema.

Marvin, Simon, and Simon Slater. 1997. "Urban Infrastructure: The Contemporary Conflict Between Roads and Utilities." Progress in Planning 48(4), 247-318.

May, John. 2011. "Infrastructuralism: The Pathology of Negative Externalities." Quaderns Accessed October 27, 2015.

http://quaderns.coac.net/en/2011/09/262-may/

McFarlane, Colin, and Jonathan Rutherford. 2008. "Political Infrastructures: Governing and Experiencing the Fabric of the City." International Journal of Regional Research 32(2) 363-374.

Miljömål.se - the Environmental Objectives Portal. 2014. Accessed October 27, 2015. http://www.miljomal.se/sv/Environmental-Objectives-Portal/

Moore, Sarah. 2012. "Garbage Matters: Concepts in New Geographies of Waste.” Progress in Human Geography 36, 780-799.

Moss, Timothy. 2008. “Cold spots' of Urban Infrastructure: 'Shrinking' Processes in Eastern Germany and the Modern Infrastructure Ideal." International Journal of Urban and Regional Research 32(2), 436-451.

Neuendorff, Rolf. 2009. Förstudie PCB $i$ oljekabel: En studie av sannolik mängd PCB som kan förekomma i svenska oljekablar. Report to SEPA.

Nye, David. 2010. When the Lights Went Out: A History of Blackouts in America. Cambridge: MIT Press.

Palm, Viveka, and Catarina Östlund. 1996. "Lead and zinc flows from technosphere to biosphere in a city region." The Science of the Total Environment 192, 95-109.

Petroski, Henry. 1985. To Engineer Is Human: The Role of Failure in Successful Design. London: Macmillan.

Pinch, Trevor, and Bijker, Wiebe. 1987. "The Social Construction of Facts and Artifacts: Or How the Sociology of Science and the Sociology of Technology Might Benefit Each Other." In The Social Construction of Technological Systems, by Wiebe Bijker, Thomas P. Hughes and Trevor Pinch. Cambridge MA: MIT Press. 
Rauch, Jason. 2009. "Global Mapping of $\mathrm{Al}, \mathrm{Cu}, \mathrm{Fe}$, and $\mathrm{Zn}$ In-Use Stocks and In-Ground Resources". Proceedings of the National Academy of Sciences 106(45), 18920-18925.

SFS 1998:808 Miljöbalken. Stockholm: Miljödepartementet.

SFS 2011:927. Avfallsförordning. Stockholm: Miljödepartementet.

Sköld, Berit. Personal archive of private cables in Norrköping. Municipality of Norrköping.

Star, Susan-Leigh. 1999. "The Ethnography of Infrastructure." American Behavioral Scientist 43(3), 377-391.

Summerton, Jane. 1994. "Introductory Essay: The Systems Approach to Technological Change." In Changing Large Technical Systems. Jane Summerton (ed.) Boulder: Westview Press.

UNEP. 2010. Metal stocks in society. International Panel for Sustainable Resource Management, Working Group on the Global Metal Flows: United Nations Environment Programme.

Wallsten, Björn, Annica Carlsson, Per Frändegård, Joakim Krook and Stefan Svanström. 2013a. "To Prospect an Urban Mine: Assessing the Metal Recovery Potential of Infrastructure 'Cold Spots' in Norrköping, Sweden." Journal of Cleaner Production 55, 103-111.

Wallsten, Björn, Nils Johansson and Joakim Krook. 2013b. "A Cable Laid Is a Cable Played: On the Hibernation Logic Behind Urban Infrastructure Mines." Journal of Urban Technology 21(3), 85-103.

Wallsten, Björn, Magnusson, Dick, Andersson, Simon and Joakim Krook. 2015. "The Economic Conditions for Urban Infrastructure Mining: Using GIS to Prospect Hibernating Copper Stocks." Resources, Conservation and Recycling 103, 85-97.

Weber, H., and Salehabadi, D. (2012) "Unmaking Technologies: The Afterlife of Discarded Artifacts and Systems", Call for Papers: "Unmaking Technologies" Panel, Society for the History of Technology (SHOT) Annual Meeting, (Copenhagen) 4-7 October.

Zittel, Werner. 2012. "Feasible Future for the Common Good: Energy Transition Paths in a Period of Increasing Resource Scarcities." Progress Report 1: Assessment of Fossil Fuels Availability and of Key Metals Availability. Vienna: Sustainable Europe Research Institute. 